\title{
JÜRGEN MOLTMANN AND THE THEOLOGY OF THE CROSS IN THE JOHANNINE PRIESTLY PRAYER
}

\author{
Matthew Michael \\ Old and New Testament \\ Stellenbosch University \\ ETSK, Nigeria
}

"The ecumenical unity of the Church can only be a unity in Truth, and this Truth which enables (and demands) unity is the all-embracing and all-saving truth of his sacrificial death on the Cross at Golgotha. The internal basis of the ecumenical movement is found in the Priestly Prayer of Christ himself: '... that they may be one"” (Jn. 17:21).

- Jürgen Moltmann

\begin{abstract}
Based on the cross-centred ecumenism of Moltmann, this article describes the problems of ecumenism among the churches of the global south. While acknowledging the paradigmatic shift in the centre of Christianity to these regions, it notes the problematic character of this shift for ecumenism especially in Africa. Situating Moltmann in discourse to the Johannine priestly prayer, it explicates some defining aspects of Moltmann's cross-defined ecumenism for the African church. In this regard, the paper describes the problems as well as prospects that this christocentric mapping of Moltmann's thought provides for the unity of the churches in Africa.
\end{abstract}

Key Words: Moltmann; Ecumenism; Christology; Johnanine Gospel;African Church

\section{Introduction}

Within the contemporary discourses on church's growth in the global south, there is an obsession with the numbers and statistics, which for better or worse, has described the sensational movement of Christianity from the West to the regions of Africa, Asia and Latin America. ${ }^{1}$ In the excitement of this paradigm shift, there are three important

\footnotetext{
See Philip Jenkins, The Next Christendom: The Coming of Global Christianity, Oxford and New York: Oxford University Press, 2002; idem, The New Faces of Christianity: Believing the Bible in the Global South, Oxford and New York: Oxford University Press, 2006; Idem, God's Continent: Christianity, Islam, and Europe's Religious Crisis, Oxford and New York: Oxford University Press, 2007. On the other hand, several studies have suggested the growth of African initiated churches in Europe, thus underscoring the global character in the growth of African Christianity. For example, Jehu Hanciles has studied the exportation of African Christianity to the West through migration [See Hanciles, Beyond Christendom: Globalization, African Migration and the Transformation of the West, Maryknoll: Orbis, 2008:350-73, 207-28]. Similarly, Adogame Afe and Kwabena J Asamoah-Gyadu have underscored the thriving of African Christianity in the former Soviet Republic [Adogame Afe, "Up, Up Jesus! Down, Down Satan! African Religiosity in the Former Soviet Bloc - the Embassy of the Blessed Kingdom of God for All Nations," Exchange 37, no. 3 2008:310-334].
} 
oversights which this excitement has failed to address clearly. ${ }^{2}$ First, the increasing presence of Christianity in these regions comes also closely at the heel of political and religious instabilities which had historically exploited the precarious scenarios for parochial local or tribal politics. ${ }^{3}$ In this same region, there are also the direct duplications of the various confessional conflicts of the European and American types which are restaged with new converts taught to see and treat people of other Christian confessional traditions as the 'other' who are either treated with certain degree of suspicion or kept best at arm's-length. ${ }^{4}$ Not surprisingly then, the inter-denominational battles of the European and American churches are given expressions and recharged significance on the African continent, with African Christians fighting each other on the basis of their differing confessional traditions. ${ }^{5}$ It is ecumenically frustrating that African Christians of Roman Catholic and Protestant camps in the twentyfirst century still live in perpetual suspiciousness of each other, thereby recreating the enmity of the sixteenth century Protestant reformation or the direct equivalent of this same reformation by the Council of Trent. ${ }^{6}$ It appears that the ghost of Luther and the debates at the Diet of Worms in the sixteen century have continually haunted the African Christians till now, often dividing them into differing confessional camps. ${ }^{7}$ It is spiritually disturbing that African Protestant and Roman Catholic intellectuals live in sixteenth century European-defined mental and ecclesiastical space where the policies of exclusion and isolation are the chief norms. ${ }^{8}$ Significantly, it seems we

2 Concerning this excitement in the shift of Christianity from the West to Africa see Kwame Bediako, Christianity in Africa: The Renewal of Non-western Religion, Edinburgh: Edinburgh University Press Ltd, 1995; Idem, "Jesus in the African Culture: A Ghanaian Perspective," Emerging Voices in Global Christian Theology, (ed.) William A Dyrness, Grand Rapids, Michigan: Zondervan Publishing House, 1994; idem, "Understanding African Theology in the $20^{\text {th }}$ Century," Themelios $201994: 14-20$. See also Andrew Walls, "Of Ivory Towers and Ashrams: Some Reflections on Theological Scholarship in Africa," Journal of African Christian Thought 3, no. 1 2000:12-23; idem, The Missionary Movement in Christian History. Studies in the Transmission of Faith, New York, NY: Orbis Books, 1996.

3 For example, see Piet Konings, "Religious Revival in the Roman Catholic Church and the Autochthony-Allochthony Conflict in Cameroon," Africa 73, no. 1 2003:31-56; See also Robert Mbe Akoko and Timothy Mbuagbo Oben, "Christian Churches and the Democratization Conundrum in Cameroon," Africa Today 52, no. 3 2006:25-48.

4 On the place and location of 'otherness' and oneself in a context of conflict see Miroslav Volf, Exclusion and Embrace: A Theological Exploration of Identity, Otherness, and Reconciliation, Nashville: Abingdon Press, 1996.

5 John Pobee and Gabriel Ositelu speak of the "Euro-American captivity of the gospel as represented by the historic churches." See John Pobee and Gabriel Ositelu, African Initiatives in Christianity, Kenya: Action Publishers, 1998:3. John Parratt also ,mentions "the regional differences of theological emphasis that have come about as result of the history of missionary penetration." See John Parratt, Reinventing Christianity: African Theology Today, Grand Rapids: Wm B Eerdmans Publishing Company, 1995:18.

6 We often forget that the story of the Council of Trent, and one could also add, the reformation is "as much a political as a theological and ecclesiastical story," John WO'Malley, Trent: What Happened at the Council, Cambridge, MA: Harvard University Press, 2013.

7 In the history of the church in Africa, the church has played a divisive and ambiguous role. For example, rather than quelling ethnic, political and confessional tensions, the church often exacerbates them. See Gérard Prunier, "The Catholic Church and the Kivu Conflict," Journal of Religion in Africa 31, no. 2 2001:139-162; see also David P Sandgren, Christianity and the Kikuyuland: Religious Divisions and Social Conflict, New York: Peter Lang, 1989.

8 Unfortunately even in the West where these confessional exclusions originated, they have now given way for more interaction and discourse across different confessional divides. For discourse between Moltmann and Roman Catholics see for example, Timothy Harvie, "Jürgen Moltmann and Catholic 
have denominationally 'imprisoned' ourselves 'in an ecclesiastical monologue' which had sentimentally barred inter-confessional discourses. ${ }^{9}$ In this ideological role, confessional beliefs are traditionally promoted, and these narrowed teachings are passed on to unsuspecting members of our different denominations. ${ }^{10}$

Unfortunately, this divisive confessional landscape did not allow the harnessing of the human and Christian resources of this region for the blessing of the church universal. ${ }^{11}$ In addition, this religious terrain also continually renegotiates and sabotages the universal claims of the Christian faith and its inter-denominational status by the narrow focus on the individual character of the denomination under a limited scope of reference. ${ }^{12}$ Through this restrictive prism, the universal inter-connectedness among Christians is lost and in its place a myopic vision of the church is imposed on her membership. ${ }^{13}$ This narrowed perspective often does not celebrate the unity of the Christian church and the common biblical heritage which binds together all Christians in time and space. ${ }^{14}$ It is within this projected variegated denominationalism that engagement of Jürgen Moltmann and the Johannine priestly prayer assumes an important function. ${ }^{15}$ Consequently, in this article, we engage the place of the cross in Moltmann's reading of the Johannine priestly prayer and the attending importance of

Theology: Disputes on the Intersections of Ontology and Ethics," The Heythrop Journal LV 2014:364-374.

9 See Warren A Quanbeck, “Editorial,” Theology Today 24, no. 1 1967:5.

10 There are other contextual factors which enhance this volatile confessional background. For example, in Nigeria ethnic, political factors often informed religious tensions or even violence in intra as well as inter-religious conflicts. Considering this, Sunday Agang has suggested the impact of these varying dimensions to the problem of religious violence in Northern Nigeria. On this study see Agang, The Impact of Ethnic, Political and Religious Violence on Northern Nigeria, and a Theological Reflection on its Healing, Carlisle, Cumbria: Langham Partnership International, 2011.

11 In tandem to this also, the church of the global south has increasingly received a negative image in the silence and siding of the church's leadership with the elites in power against the teeming masses that attend her worship. Similarly, in many places in Africa, the elites are the direct creation of the church through her initiative in pioneering education, thus most elites have sympathetic feelings towards the church. When appropriate, African churches often take advantage of this sentiment, in order to exercise a direct confessional influence over a particular region, which often sabotages the ministries of other confessions. This scenario usually exacerbates renewed interdenominational tensions. For example see JF Ade Ajayi, Christian Missions in Nigeria 1841-1891: The Making of a New Élite. Ibadan History Series, London: Longmans 1965.

12 Rather than defining our worldviews and religious convictions in a narrowed space, we need to see the broadness of realities. For example, Moltmann saw his life in this broad perspective rather than the product of a narrowed confession. See Jürgen Moltmann, A Broad Place: An Autobiography, London: SCM Press, 2007.

13 While the problems of suspicion, division and sectarian concerns are not particularly unique to the African church, the work engages these problems as manifested in Africa and shows the expressions of these global problems in the African church. Similarly, the use of Moltmann is appropriate here because of the importance of Moltmann in modern Christian theology. Consequently, the article provides an engagement of a global problem from its local expression in Africa, and uses the thought of Moltmann on Jesus' priestly prayer to understand this global problem.

14 On the study of time see Jürgen Moltmann, "What is Time? And How Do We Experience It?" Dialog: A Journal of Theology 39, no. 1 2000:27-34.

15 Moltmann has become a defining figure in modern theology particularly in his ability to engage the Majority world. Several works underscore Moltmann's interest in the Majority World. See for example, Geiko Müller-Fahrenholz, The Kingdom And The P ower: The Theology Of Jürgen Moltmann trans. John Bowden, Minneapolis: Fortress Press, 2001; Susanne Hennecke, "Related By Freedom: The Impact of Third-World Theologians on the Thinking of Jürgen Moltmann," Exchange 32 no. 4 2003:292-309; Leopoldo Cervantes-Oritz, "God, the Trinity, and Latin America Today," Journal of Reformed Theology 3 no. 2 2009:157-173. 
his theological constructions in addressing the inter-denominational identity of the African church, particularly in its new status as the powerhouse of the 'Next Christendom.' 16

\section{The Johannine Priestly Prayers and Moltmann's Thought on Ecumenism}

Christian unity is neither an appendix nor an addendum in Moltmann's theology, but occupies a central importance in his thinking as clearly attested in his personal involvement in global ecumenism. In his work, 'Ecumenism beneath the Cross' for example, Moltmann suggested two bases for Christian unity namely the internal and external bases. ${ }^{17} \mathrm{He}$ located the internal basis of Christian unity primarily in the Johannine priestly prayers of Jesus, when Jesus says, "That They may be one, Father, just as you are in me and I am in you. May they also be in us so that the world may believe that you have sent me" (John 17:21). ${ }^{18}$ For Moltmann, the heart of Christian unity in all its dimensions should be located in this prayer of Jesus. However, he also underscored the necessity of unity based on what he described as 'external stimulus.' He observed, "The external stimulus for the communion of Christians upon earth lies in the catastrophic 'sufferings of this age.' Only through ecumenical communion within itself, can Christianity witness the peace of God to this divided, oppressed and disturbed world."19 In this thought, Moltmann surmises that Christians should be united in attending to the healing of the world, in caring for the sick, helping the poor, and reaching out across the structured divisions along race, gender, denomination or religions. ${ }^{20}$ In spite of the significance of this basis for Christian unity in meeting the general needs of humanity, Moltmann placed greater significance on the internal basis of Christian unity, thus in this sense, reiterating the importance of Jesus' priestly prayer. ${ }^{21}$ On this, he said:

However, the inward basis [of Christian unity] takes precedence over all external motives; for the renewal, liberation and unification of the Church of Christ upon earth will result not primarily from theological strategy and ecclesiastical tactics of drawing together, but rather from the very root and well-spring of the Church, namely from the power of Christ's own Passion; since in his outpoured blood and in his opened heart the Church is already renewed, liberated and one. The

16 Jenkins, The Next Christendom, 1-17.

17 He presented this paper in WCC conference at Nairobi, Kenya in December, 1975. For the second part of this paper on Ecumenism see Moltmann, "Ecumenism Beneath the Cross: Part II," AFER no. 2 1977:1-9.

18 Moltman's experiences were defining in the formation of his thought on unity and hope. For this investigation see Agang, The Impact of Ethnic, Political and Religious Violence, 131-142.

19 Moltmann, "Ecumenism Beneath the Cross: Part I," AFER no. 1 1977:314.

20 Moltmann has saliently engaged the Pentecostals in discourse. He greatly applauds their holistic pneumatology. See Moltmann, The Spirit of Life, London: SCM Press, 1992; idem, The Church in the Power of the Spirit: A Contribution to Messianic Ecclesiology, London: SCM Press, 1977; Moltmann, "The Mission of the Spirit: The Gospel of Life', in Timothy Yates, (ed.) Mission - an Invitation to God's Future, Sheffield: Cliff College Publishing, 2000), 19-34. On the response to Moltmann's discourse with Pentecostalism see Andrew Lord, "The Pentecostal-Moltmann Dialogue: Implications for Mission," JPT 11, no. 2 2003:271-287.

21 In Moltmann, one finds a blending of theological doctrines which complement each other. For example, Moltmann has described the intersecting connection of theology thus, "There can be no Christology without eschatology and no eschatology without Christology." See Bauckham, (ed.) The Theology of Jürgen Moltmann, Edinburgh: T\&T Clark, 1995:100. 
ecumenical movement towards the unity of the Church is, in its essence, a movement coming from the Cross of the one Lord (emphasis in the original). ${ }^{22}$

Located on this internal premise, Moltmann emphasizes the basis of Christian unity in the revealed truth of the gospel, particularly the events of the cross. ${ }^{23}$ From this perspective, Moltmann situated ecumenism in Christology and not in the arena of practical theology or other forms of social services from the church to the world. Christology, in this sense, becomes a framework around Christian unity. Considering this Christological commitment, Christian unity ceases to originate from a humanistic quest to better the lots of other human beings, but it must be established, according to Moltmann, on the person and works of Christ. Moltmann's Christological template further covers five theological areas which further exemplify the priestly prayer of Jesus and thus underscore the unity of the church. In fact, there is a sense in which Christian unity is considerably predicated on Moltmann's Christological template. First, Moltmann notes that Christian unity must move from eccle-siologies and confessional traditions in order to resituate itself in commitment to the person of Christ. ${ }^{24}$ In this regard, he observed:

We have recognised that we can make no genuine progress towards unity by merely comparing our various conceptions of the Church's essence and the traditions inextricably bound up therewith. It has become clear that we approach each other, to the extent that we approach Christ. Hence we must penetrate through our divisions to a deeper and richer understanding of the mystery of unity given us by God in Christ, with the Church.' This movement from purely external comparison of ecclesiologies to an inwardly-binding, christological ecclesiology has since then pointed the way for ecumenism: The nearer we come to Christ, the nearer we come together (emphasis in the original). ${ }^{25}$

Consequently, for Moltmann, there should be a movement away from the temptations to compare and to contrast the different confessional positions and their theological traditions rather than coming 'nearer' to Christ. Significantly, hidden in this assertion lies a polemics against various Christian ecclesiastical traditions because it seems from Moltmann's analysis, that ecclesiastical traditions could conceal from its membership the lordship of Jesus and his centrality in Christian unity. In this premise, the church should shift away from its ecclesiastical practices which often tend to conceal the centrality of Jesus in its ecclesiastic ministries, and move in a newer direction whereby the person of Jesus is discovered and his uniting power engaged. In addition, Moltmann encourages closeness to Christ as a remedy against the feeling of alienation which many Christians of different confessional stands feel in the company of one another. For Moltmann, the statement "the nearer we come to Christ, the nearer we come together" has formidable truth because our distance from Christ is often reflected in our experience of distance from each other. Our distance from Christ is

22 Moltmann, "Ecumenism Beneath the Cross," 314.

23 Similarly, Moltmann also proposed a Christological engagement of the modern society in the context of renewed violence and terrorism. On this study see Moltmann, "Hope in a Time of Arrogance and Terror," ICJ 3, no. 2 2003:157-167.

24 Moltmann is critically anti-monotheistic in his theological orientation. He places emphasis on the trinitarian character of God rather than the monotheistic description. On the critique of this antimonotheistic thought see Randall Otto, "Moltmann and the Anti-Monotheism Movement," International Journal of Systematic Theology 3, no. 3 2001:293-308.

25 Moltmann, "Ecumenism Beneath the Cross," 315. 
seen proportionately in the many incidences of failed ecumenical fellowships. Consequently, divisions and sectarian interests in the church are clear reflections of the spiritual distance between the persons in a particular ecclesiastical tradition from the person of Jesus Christ because closeness to Christ entails also closeness to other people who share this same faith.

Another important aspect of Moltmann's internal basis for Christian unity lies in the cross of Jesus. According to Moltmann, the cross and its image of suffering become a rallying point of unity for all Christians. In this frame, the cross contributes and helps to enhance the sense of unity of Christians in respect of their confessional or ecclesiastical backgrounds. While the cross of Christ showcases the suffering of the deity to the world and it might prove a stumbling block to some, Moltmann saw in the cross a perfect opportunity which levelled all people and placed them in need of Christ. ${ }^{26}$ In the cross, the Christian community sees and understands each person in his/her need of Christ, and together we become a community because, and through, the transforming power of the cross. Conceived in this sense, the cross ceases to be an object of mere devotion, it becomes an element of unity. To this end, Moltmann observed:

For the Cross is not just one object among others about which we may speak objectively. Christ's Cross is the place where we are assembled and brought together and made more deeply one than we could ever become by thought alone. Hence no dialogue concerning the Cross without standing together beneath the Cross - and no ecumenical discussion about church unity without the liberating discovery of the Church's unity within the self-offering of Jesus for the salvation of the separated. But this means yet again: the nearer we come to the Cross of Christ, the nearer we come together. ${ }^{27}$

While the former observation highlights the need to come to Christ, this immediate point encourages the need to celebrate the cross of Christ and to make the cross an object of unity. He also notes that Christian unity should be freed from the limitations and the present human obsession with the theme of unity which stems from human ideology or philosophy. For Moltmann, "Ecumenism - ecumenical church - does not come into existence because of a human vision of unity, albeit such a utopia of peace is important for humanity today, headed for a collapse on account of its divisions." Importantly, he observed, "Basically, it is not unity which brings salvation, but salvation which brings unity." 28 In this way, Moltmann separated unity from salvation and underscored the importance of salvation by given it precedence over unity.

Considering this, Christian unity, according to Moltmann, has its source in salvation and the cross. It is different from the noble quests and unified ventures by various human societies which are aimed at saving the world. On this ground, unity in Moltmann's thought is freed from human ingenuity or utopia, but it is directly linked to the cross of Jesus Christ, particularly in the saving power of Christ and its attending ability to unite people from different places. Consequently, Moltmann dismissed all human clichés such as "United we stand and divided we fall," and readjusted the focus of unity from human sphere to a divine sphere. In doing this, Moltmann thrust unity

\footnotetext{
26 See Ryan Neal, “Minority Report: Reconsidering Jürgen Moltmann's Turn to a Theology of the Cross," International Journal of Systematic Theology 14, no. 1 2012:26-43.

27 Moltmann, "Ecumenism Beneath the Cross," 315.

28 Moltmann, "Ecumenism Beneath the Cross," 315.
} 
into a divine space by the withdrawal of this entity from human sphere, and its transposition to the foot of the cross. Whether one disagrees with Moltmann here is irrelevant because his re-conceptualizing and transferal of unity from the usual human domain to one of divine space comes from the realization that human history has in spite of the ingenuity of the human spirit failed to build a unified society. Again and again, the human quest for unity has been shattered, and many human visions of lasting utopia have not been realized. ${ }^{29}$ Seeing this reoccurring failure, one would definitely agree with Moltmann that unity in any form must seek new location in divine economy and not within human dreamed projects.

Connected to the cross of Christ, Moltmann turned his attention to the place of God's powerful love which is expressed at the foot of the cross. In this regard, Moltmann noted the need to rediscover the power of love which the cross exemplifies and to reject the love for power which often stands as a barrier to lasting unity. $\mathrm{He}$ observed:

But the true Christian quality that leads to unity is not the love of power, but the power of love. Ecumenism comes into being wherever...we find ourselves beneath the Cross of Christ, and there recognize each other as brothers and sisters, hungry in the same poverty (Rom. 3:23), imprisoned in the self-same sin. Beneath the Cross we all stand empty-handed. We have nothing to offer except the burden of our guilt and the emptiness of our hearts. Beneath the Cross no count is made of Protestants, Catholic or Orthodox. There, rather, is where the godless are justified, enemies are reconciled, prisoners are set free, the poor are enriched and the sad are filled with hope. Therefore, we discover ourselves beneath the cross both as children of the same freedom of Christ and as friends in the same fellowship of the Spirit. The nearer we come to Christ's Cross, the NEARER we come together. How can our divisions and our enmities be maintained in the sight of his bitter suffering and death? How, in the light of Christ's pierced heart, can we remain closed, and be fearful about the Church? And how can we, grasped by the outstretched arms of the suffering God upon the Cross, tighten our fists or with unrelenting fingers hold fast to our confessional separations? (Emphasis in the original). ${ }^{30}$

Working on this premise, Moltmann described the foot of the cross as a level field where individual status, economic class, confessional affiliations and diverging doctrines do not arise. In this space, everyone stands and falls not on his or her own merits but on the merits of Christ's sacrificial death. At the foot of the cross, therefore, we find a levelled place to build and to formulate a new vision of unity which is devoid of class considerations and social hierarchies. Founded on this playing field, a Christian sense of unity must rediscover the oneness and unity that comes from our sense of sinfulness at the foot of the cross. In this place we must also recover our sense of redemption as provided by the death of Jesus Christ in this same liminal space. Consequently, on this important note, Moltmann placed Christian unity at the foot of the cross and thereby seeks to distance Christian unity from the imposing influences of personality, ego, denominational pride and ecclesiastic selfcenteredness.

29 See Moltmann, Theology of Hope: On the Grounds and Implications of a Christian Eschatology, trans. James Leitch, Minneapolis: Fortress Press, 1993, idem, The Coming of God's Christian Eschatology, London: SCM, 1996; On the critique of the same work see Richard Bauckham, God Will Be All In All: The Eschatology of Jürgen Moltmann, Edinburgh: T\&T Clark, 1999. 
Thirdly, Moltmann also saw Christian unity connected to the passion of Christ. He began his discourse on the passion of Christ by investigating the origin of the church. For Moltmann, the church did not originate only on the day of Pentecost, but it came into existence at the pain and suffering of Jesus Christ through the cross. He observed:

The true origin of the Church lies in the self-giving of Christ unto death upon the Cross. The Passion of Christ is representative suffering for the pardon and redemption of the world. Christ's death-pangs are thus the birth-pangs of the Church, which extends his services of reconciliation in this unredeemed world.

From the suffering of the Messiah, the messianic People is born. ${ }^{31}$

Within this premise of Christian unity, Moltmann saw the church as the product of Christ's passion on the cross. In this sense, the pains and sufferings of the church gave birth to the church. He also noted the necessity of every true church to return to this common origin. The different confessions and endless doctrinal positions must be reconstructed in order to experience the unifying power of Christ's passion. For Moltmann, this is the only tradition that supersedes all other ecclesiastical traditions. He said, "Whenever in the ecumenical movement, separated Churches go back from their differing traditions to this one tradition from which they all live, at that moment they come back from their branching streams to the one fountainhead" (emphasis in the original). ${ }^{32}$ For Moltmann, "this original Paradosis is the handing-over of the Son by the Father in order to grant acceptance to the rejected and lost among mankind, at the Cross on Golgotha." ${ }^{33} \mathrm{He}$ added, "All Christian tradition draws life from this salvific Tradition (= handing-over) of Christ by God his Father, to death in abandonment." 34

Fourth, Moltmann retrieved the unifying power of the Eucharist/mass to assert and underscore a powerful base for Christian unity. For Moltmann, the 'invitation' of Jesus Christ at the Lord's Supper "is without limits and without conditions." ${ }^{35} \mathrm{He}$ further observed:

The invitation to the eucharistic meal is the inciting request of the dying Christ, who was handing himself over for us. It is the crucified Christ himself who invites the poor and the guilty to the table of God's Kingdom. That is why his welcoming hands are just as wide open at the eucharistic meal as were his outstretched arms upon the Cross. The invitation to eucharistic fellowship in his name is open to all the world, excluding nobody but including all. However, it is still a qualified openness. It is qualified by the bitter sufferings and death of the Son of Man. ${ }^{36}$

Like many of the parables of Jesus about the invitations to eat at the banquet of God's kingdom, the Eucharist is seen by Moltmann as having similar unconditional invitation to all. In the Eucharist meal, the church is called to exemplify or to serve as the foretaste of this kingdom to come. ${ }^{37}$ He noted that it is the 'Lord's supper,' and not 'the church's supper. ${ }^{38}$ Moltmann dismissed the disunity promoted by various

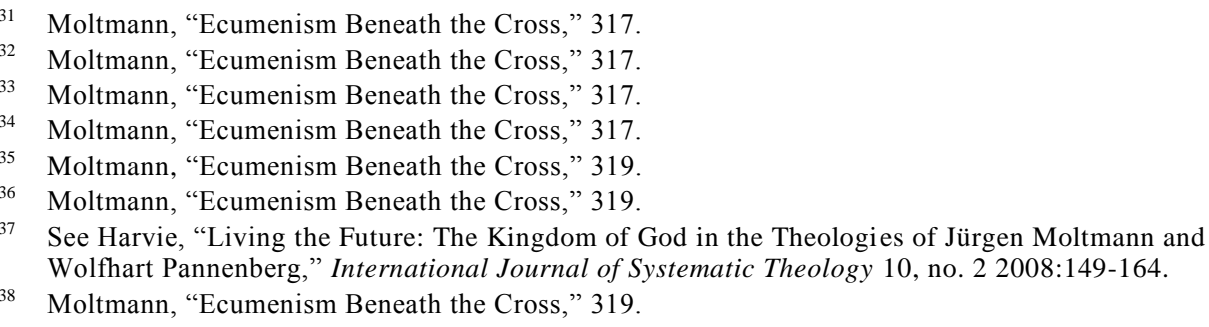


confessions who bar people from partaking from the Lord's Table. ${ }^{39}$ From the preceding reflections, Moltmann places the essence of Christian unity in Christology particularly in the person, cross, and Eucharist of Jesus Christ. In situating Christian unity in Christology, Moltmann also underscored and explicated the significance of the priestly prayer of Jesus Christ where Jesus prayed for the Church to be united with the same degree of unity which characterizes the three persons of the Trinity. In relocating unity to the centre of Christology, Moltmann further described the significance and particular instances in the life of Jesus Christ where unity is reflected. However, he gave priority to the cross of Jesus. In this way, the cross ought to provide the theological resources needed by the church in order to enhance and to build its need of unity. For Moltmann, the foot of the cross provides a neutral ground where each denomination could work with each other in order to achieve and realize a true Christian identity. Three merits of this proposal by Moltmann are worth noting. First, it seeks to take every Christian denomination away from the intricate web of doctrinal confessions and affiliations and to the centrality of Jesus Christ as the corner of Christian unity. In this regard, the proposal by Moltmann achieves a degree of unified framework on which the unity of the church could be formed.

Secondly, Moltmann's proposal opens the doors of the church to the world rather than the exclusion of the world from the Eucharist and other activities of the church which Moltmann saw as a part of the self-giving of Christ to the world. Third, Moltmann rejected any form of human visions and utopiac ideologies as foundation for Christian unity; instead he saw the world's inability to bring about the unity of the human race on the basis of human endeavours. Lastly, in Moltmann's proposal there lies an element of optimism or hopeful belief that the church could be united if she placed and emphasized the cross as the basis for the church's unity. ${ }^{40}$ In this optimism, one sees a hope-oriented worldview in Moltmann's proposal which has now become the trademark of his theology.

In spite of these merits, three weaknesses of Moltmann's proposal readily emerge. First, there is no gain-saying that the cross forms an important part of the universal church's faith; however, often even this central element is seen and treated differently by various Christian communities, so that it becomes almost impossible to assert a unifying framework as suggested by Moltmann. Secondly, Moltmann's thesis that Christian unity lies in the appropriation of the Christ-events places Christology at the centre of the modern quest for church unity. Moltmann sounded as if this alone should be the basis for Christian unity. Is it not also possible to create a framework of

39 He added, "Hence, I see no reason why any church should hold back the open and pierced hands of Christ which are outstretched towards all. I find no right to refuse eucharistic fellowship to anyone who hears and answers the invitation of the Crucified One. It is not the eucharistic fellowship of all Christians which must be justified; that is already justified by the right of Christ's grace upon the Cross. Rather, what does need to be justified is each exclusion, each refusal, and each holding-back. But how can these be justified, when we are dealing with the Lord's Supper and not with something arranged by a church? The Lord himself invites the poor to his meal in order to enrich them through his poverty; it is not just the invitation of a Confession to its own members. The invitation is from the friend of sinners and tax-gatherers - to grant freedom and justification to the abandoned - and not from a particular group to its participants. Whoever takes the Cross seriously begins to feel pain at the division of the churches. He takes part in the suffering of Christ who through these divisions is himself 'divided' (I Cor. 1:13); but this situation is intolerable and must be overcome." Moltmann, "Ecumenism Beneath the Cross," 319.

40 For Moltmann's critique of optimism in the present modern society see Moltmann, "The Crucified God," Theology Today 31, no. 1 1974:6-18. 
Christian unity from pneumatology, theology proper, or even eschatology? Are there not elements within these spheres of theology which could be employed also in order to build a theology of Christian unity? It appears his Christocentric direction for the church's unity did not fully harness the theological resources in the related doctrinal confessions of the church. Lastly, Moltmann's proposal fails to account adequately for the role of external factors such as the tradition and ecclesiastic practices of the church in harnessing and the development Christian unity among different churches. For Moltmann, the internal basis of unity transcends the external forms and thus appears to neglect the critical role complementing traditions could play in forging the desired Christian unity.

In spite of the preceding flaws, Moltmann showcased or articulated fully the details in the priestly prayer of Jesus, particularly in the desire of Jesus that his followers should be one. Even though the Johannine text rightly placed the unity of the church by drawing its attention to the godhead, Moltmann departed from here and asserted the defining role of the cross and Christian unity. It appears Moltmann saw the extension of the priestly prayer of Jesus beyond the confinement of his immediate life to include his death on the cross. In this way, Moltmann seems to have suggested that the entire atonement of Christ is and become the basis for the unity of individuals in the church. Seen in this way, the priestly prayer of Jesus is resituated from its trinitarian location in the godhead primarily to define the person and work of Jesus particularly his sacrificial death on the cross. ${ }^{41}$

Considered in this way, the cross of Jesus becomes the true expression as well as foundation for the realization of the priestly prayers of Jesus. In the cross, according to Moltmann, Jesus provided all the spiritual resources needed to realize his priestly prayer. Consequently, Moltmann saw the death of Jesus in respect to its unifying power and directly perceived the cross as the realization of Jesus' prayer "that they may be one." For Moltmann, the cross answers this prayer and every person who continually stands beneath the cross will see all other persons there as brothers and sisters. The cross becomes the main path by which the priestly prayers of Jesus were answered because there we are giving the necessary spiritual motivation to see and experience the unifying power of the cross of Jesus.

\section{The African Church and Moltmann's Template of Hope}

The African church is located at the spiritual latitude of increasing ecclesiastical complications with emerging churches and the existing ones lacking the fundamental resources to enhance as well as underscore the unity within the body of Christ. The priestly prayer of Jesus is far from being realized. The orthodox, Pentecostal and African Independent churches have failed to see each other as brothers and sisters in Christ. Describing this scenario, NH Ngada and KE Mofokeng said, "[i]n the process of becoming free and independent, we became very divided and even, at times isolated from one another. Much of our struggle in recent times has been for unity and cooperation amongst the indigenous Churches themselves." 42 The situation is exacerbated with increasing doctrinal and confessional emphases which further estranged

\footnotetext{
41 Several critiques of Moltmann's descriptions of the unifying essence of Trinity have been made. For example see John Meyendorff, "Reply to Jurgen Moltmann's 'The Unity of the Triune God," ST. Vladimir's Theological Quarterly 28, no. 3 1984:183-188.

42 Ngada and Mofokeng, African Christian Witness, Pietermaritzburg: Cluster Publication, $2001: 18$.
} 
these churches from one another. There is also the increasing suspicion of African ecclesiastical leaders of each other which make dialogue and ecumenical aspirations difficult to realize. In addition, the political apparatus of the state often engineered and exploited these confessional tensions for political ends, thereby further putting at jeopardy the little rays of hope in the midst of this estrangement among the different confessional stands of the African society. Coming from this context, it becomes nearly impossible to talk of unity and the unifying power of Jesus Christ.

However, it is in the midst of this tension, mutual suspicion and increasing interdenominational estrangements that the theology of Moltmann becomes not only relevant but also appropriate by its powerful relocation of Christian unity from our individual confessions or churches to the levelled space at the foot of the cross. The African church needs to recover the theology of the cross particularly in the unifying power of the cross, to bring together people from different racial, confessional and even religious stands. The theology of the cross takes every denomination or confession back to the basics or the starting point before the ecclesiastical complications and religious bureaucracies, which often conceal the common heritage shared by every Christian, namely we that were forgiven, cleansed and reconciled at the foot of the cross. Therefore, we could also engage in the work of forgiving others and reconciling with others because we have experienced the power of the cross. The cross is the essence of Christianity and it is necessary for the African church to daily experience and resituate itself beneath the cross of Jesus Christ, and to receive the spiritual resources needed to enhance or even engender the needed cooperation and unity among various confessions that emphasized the lordship of Jesus Christ. Applying Desmond Tutu's insight in speaking of the unity of the South African people is appropriate here. Tutu described the South African people as a 'rainbow nation.' He observed:

We have sought to point out that a rainbow is a rainbow precisely because it has different colors. We are a rainbow nation because of our diversity. We should celebrate our differences, we should affirm them because they make us need one another since it is clear none of us is self-sufficient. We need others in order to be human. $^{43}$

We also need a 'rainbowed ecclesiology' whereby all the beautiful colorations in various African Christian communities are deliberately blended and duly celebrated. Within this viewpoint, the African church must be willing to experience as well as communicate the power of love exhibited at the cross. She must also be willing to share this same forgiving and reconciling love with the other brothers and sisters in her midst who confess the same or different confessional stands. Importantly too, we must be united in seeking justice for the oppressed and providing hope for African people across denominational divides. In this sense, unity should also transcend mere ecumenical pronouncements, but should include a collective desire to address the unjust conditions of the African people. Maluleke observed, “...aspiring to some grand unity of all ...was a warped and deficient form - a 'catholicity' without justice, dignity, coherence or a sound eschatology..." Consequently, we must rise above denominational self-centredness, the false security of ecclesiasticism, and the

43 Tutu, "Horizons," Diogenes 44, no. 4 1996:205.

44 Maluleke, "Of Collapsible Coffins and Ways of Dying: The Search for Catholic Contextuality in African Perspective," Ecumenical Review 54, no. 3 2002:315. 
confessional illusions which keep the African church variegated and divided against itself. Here, Moltmann provides us with important grounds for unity by pointing us back to the cross as the basis of Christian unity in respect of denominational differences or confessional divisions. In doing this, the African church would seek to negotiate or even renegotiate its present shattered identity by offering hope and care to the many members of different confessions at the foot of the cross. Offering hope of unity in the absence of the cross is no hope at all. Moltmann rightly observed that "there is no true theology of hope which is not first of all a theology of the cross." 45 The theology of the cross should give rise to hope - particularly the hope of unity among the African churches. Consequently, the African church as the "Next Christendom" must move from the many intra and inter-denominational squabbles in order to assert its relevance and importance on the religious map of the global church.

\section{Conclusion}

Moltmann considered Christian unity in Christocentric perspectives. He rejected the tendencies in human societies to seek unity outside of Christ. For Moltmann, it was only as the church lives again and again within the purview of the cross that it becomes and realizes the unifying divine intention of its essence. According to Moltmann, the nearer we are to Christ, the nearer we are to each other and to see each other as brothers and sisters in respect of our individual perceptions or confessional convictions. Unfortunately, the distance from Christ often increases distance experienced between different confessions within the Christian communities, thereby making Christian unity unattainable. As members of different confessions, we must also realize that the cross defines our common destiny in God. For example, Moltmann said, "We come from different traditions and live in different cultures, but we are going to meet the one, same parousia of God's kingdom, which binds us all together. Our origins are very different, but our future in God is one." 46 In this common destiny 'in God' and future, and our common heritage in Christ at the cross, we can now in trinitarian perspective allow the power of the Holy Spirit to steer our hearts toward engendering unity among us. This unity cannot be founded on the various ecclesiastical apparatus or distinctive confessional stands of our different churches, but upon the common heritage at the cross and the recognition of our common destiny as people of God, who will live together at the eschaton where in Isaianic vision the lion will dwell together with the lamb (11:6-9). Viewed in this way, the priestly prayer of Jesus is actually an expression of our common heritage at the cross and our common destiny as God's people at the end of time. Consequently, the priestly prayer ceases to be a prayer from this perspective but the essence, heritage and destiny of all God's people.

45 Moltmann, "The Crucified God," 8

46 Moltmann, "The Blessing of Hope: The Theology of Hope and the Full Gospel of Life," Journal of Pentecostal Theology 13, no. 1 2005:148. 